\title{
Study of chromosome composition of the southern Ural genotypes of Prunus pumila L. by various methods
}

\author{
Mikhail S. Lyozin ${ }^{1, *}$, Sergey V. Asbaganov ${ }^{1}$, Olga V. Mochalova ${ }^{2}$, Dmitry A. Gusev $^{2}$, and \\ Vladimir S. Simagin ${ }^{1}$ \\ ${ }^{1}$ Central Siberian botanical garden of SB RAS, 630090, Novosibirsk, Russia \\ ${ }^{2}$ Lisavenko Research Institute of Horticulture for Siberia, Barnaul, Russia
}

\begin{abstract}
Prunus pumila L. is a winter-hardy Siberian species widely used in kitchen-gardens, as well as in nurseries as a seed stock for plums and apricots and development of hybrids for stocks of these cultures. Rare cases of emergence of polyploids among introduced seedlings are known. Chromosome numbers of 11 morphologically different plants of this species from Chelyabinsk Oblast were studied in comparison with some plants from Barnaul with already known ploidy by cytological and cytometric methods. With the help of both methods it was established that all plants from Chelyabinsk Oblast turned out to be diploids. Ploidy of the control specimens from Barnaul was supported by the cytometric method. A rare emergence of polyploids when introducing P. pumila in the climatic conditions differing from the natural ones was confirmed.
\end{abstract}

\section{Introduction}

Prunus pumila L. is a North-American species belonging to the section Spiraeopsis Koehne [1].This species has a high frost resistance, and therefore is often grown in Russia in steppificated areas of the Volga regions, the southern Urals and Siberia [2] in the kitchen-gardens and is used in nurseries as a seed stock for plums and apricorts. In this case an intraspecific diversity of seedlings is noted by various morphological features of bushes, leaves and fruits.

As all diploid representatives of this subgenus, except for Prunus prostrata Labill., it is characterized by stable diploid $(2 \mathrm{n}=16)$ set of chromosomes in somatic cells. Aberration is often linked with cultivation in atypical conditions, e.g. when introducing. Spontaneous triploid $(2 n=24)$ genotypes are revealed very seldom. I.S. Rudenko managed to find one autotriploid form differing by vegetative heterosis and poor fertility in Moldavian gene pool [3]. One tetraploid form of Prunus tomentosa L. (N 14-17 A) was found in the Altaian gene pool among seedlings from the seeds collected by G.V. Eremin in the natural population in Primorsky Krai. Seedlings from free pollination of this form (N63-25-1 and N 63-25-2) had a triploid set of chromosomes [4]. From randomly taken seeds of Prunus pumila L. for sowing it was possible to single out spontaneous triploid form $\mathrm{N} 9$ which was later used for

\footnotetext{
* Corresponding author: lezin-misha@mail.ru
} 
experiments of in vitro artificial polyploidy [5]. Up to now spontaneous autotetraploids for P.pumila have not been found.

It should be noted that unlike the representatives of a pure species, intergeneric hybrids of $P$. pumila with diploid plums turn out to be often polyploids, mainly triploids due to functioning of unreduced macrogametes. In the Altaian gene pool such triploids were found among the old genetic materials obtained in the Russian Far East, Krasnoyarsk and the Altai low mountains in the first half of the last century. Such triploids were: SVG 11-19 (a valuable stock for Ussurian plum), Seyanets Yuty, Smena, and Fialka. Sixty three triploids were found in the generations from free pollination of diploid SVG cultivars such as Pchyolka, Chulym, Novinka, Yuta, Opata, Desertnaya, Dalnevostochnaya and Lyubitelskiy [4].

Consideration of interrelation of significant morphological diversity with possible changes of chromosome composition of introduced seedlings is of chief interest. The material of our study were 11 genotypes of $P$. pumila from the nursery of the Company "Gardens of Russia" in southern Chelyabibsk Oblast which differed significantly among themselves in height, habitus, leaf and fruit features. Barnaul P. pumila genotypes with known ploidy and triploid hybrid SVG 11-19 were used in the experiment for the comparison. Our aim was study of chromosome composition of these samples by two different methods and search for possible aberrations.

\section{Methods}

For chromosome counts vegetative buds at the stage of "green cone", previously cleaned from external scales were used. They were pretreated in the mixture (1:1) of 0.002 M 8 -hydroxyquinoline and saturated solution of paradichlorobenzenel for 5 hours [6]. The buds were fixed in 3:1 ethanol: ice-cold acetic acid. The chromosomes were stained by acetic hematoxylin according to the methods of Central Genetic Laboratory [7]. They were counted on not less than 10 metaphase plates using the light microscope Jenaval (Zeiss) equipped with digital camera TC-500.

A ploidy analysis by measurement of nuclear DNA amount was also performed using flow cytometry. Currently this method is widely and successfully used in studying ploidy of various plants, including representatives of the genus Prunus L. [8,9]. Cell nuclei were isolated using buffer CyStain UV Ploidy (Partec) with fluorochrome DAPI (4,6-diamidino2-phenylindole). All procedures were carried out according to the standard protocol of manufacturer. The measurement of genome size was conducted using FloMax software on the flow cytometer CyFlowSpace (Partec, Germany). More than 5000 cell nuclei were analyzed for each of samples. This present-day method with good technological support allows to study quickly a great quantity of samples.

\section{Results}

All eleven $P$. pumila forms (N 2-27-51, 2-90-07, 2-59-07, 2-85-07, 2-24-07, B-13-18, 225-07, 2-30-07, 2-80-07, 2-18-07, and 2-50-07) for cytological study on the light microscope from the Ural gene pool turned out to be diploids $(2 n=16)$. Polyploid cells in the total mass of divisible ones observed on squashed slides were not found. Ploidy of Barnaul $P$. pumila specimens and a remote hybrid, determined earlier, was also confirmed (Table).

Cytometric research fully confirmed the data obtained in cytological study of all experimental genotypes. Despite noticeable distinctions between their morphological features, any changes in ploidy were not found. Both methods may be successfully used, 
the choice can be determined by available equipment and reagents, as well as by vocational training of specialists.

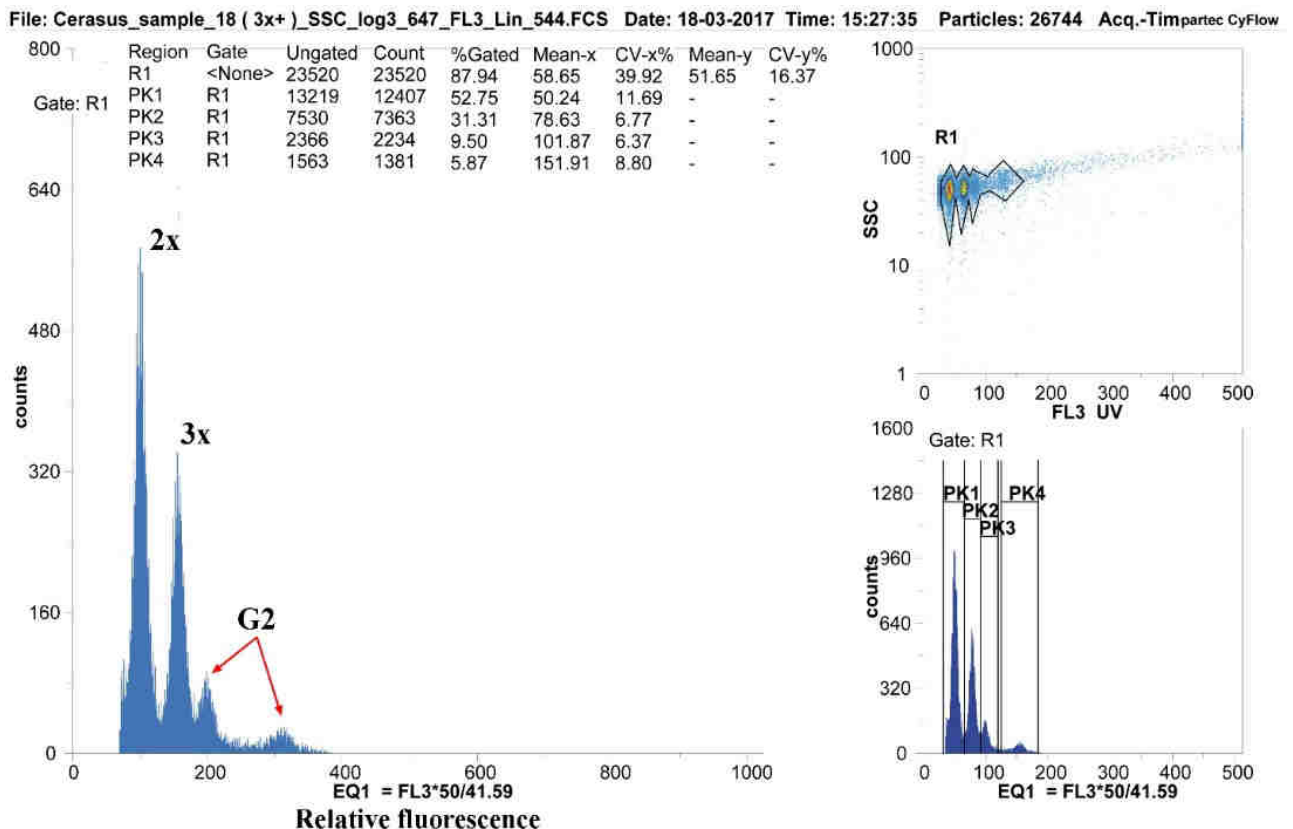

Figure. Histograms of flow cytometry, illustrating ploidy of DNA in the mixture of cell nuclei: diploid "micro P. pumila" 2-85-07 (PK1), triploid "SVG -11-19" (PK2) and corresponding peaks of fuorescence of cell nuclei in phase G2 (PK3 and PK4 ).

Table. Karyological data of studied specimens and P. pumila hybrid

\begin{tabular}{|l|c|c|c|}
\hline \multirow{2}{*}{ Samples } & \multicolumn{2}{|c|}{ Specimen Ploidy by data } & \multirow{2}{*}{ Chromosome number } \\
\cline { 2 - 3 } & Cytology & Cytofluorimetry & \\
\hline $2-85-07$ & $2 \mathrm{x}$ & $2 \mathrm{x}$ & 16 \\
\hline SVG-11-19 & $3 \mathrm{x}$ & $3 \mathrm{x}$ & 24 \\
\hline P. pumila, Barnaul & $2 \mathrm{x}$ & $2 \mathrm{x}$ & 16 \\
\hline P. pumila, Barnaul & $3 \mathrm{x}$ & $3 \mathrm{x}$ & 24 \\
\hline $2-27-51$ & $2 \mathrm{x}$ & $2 \mathrm{x}$ & 16 \\
\hline $2-90-02$ & $2 \mathrm{x}$ & $2 \mathrm{x}$ & 16 \\
\hline $2-59-07$ & $2 \mathrm{x}$ & $2 \mathrm{x}$ & 16 \\
\hline $2-24-07$ & $2 \mathrm{x}$ & $2 \mathrm{x}$ & 16 \\
\hline B-13-18 & $2 \mathrm{x}$ & $2 \mathrm{x}$ & 16 \\
\hline $2-25-07$ & $2 \mathrm{x}$ & $2 \mathrm{x}$ & 16 \\
\hline $2-30-07$ & $2 \mathrm{x}$ & $2 \mathrm{x}$ & 16 \\
\hline $2-80-07$ & $2 \mathrm{x}$ & $2 \mathrm{x}$ & 16 \\
\hline $2-18-07$ & $2 \mathrm{x}$ & $2 \mathrm{x}$ & 16 \\
\hline $2-50-07$ & $2 \mathrm{x}$ & $2 \mathrm{x}$ & 16 \\
\hline
\end{tabular}

\section{Discussion}


Both methods used showed a high effectiveness in determining ploidy. The method of flow cytometry allows to quickly to obtain data on DNA ploidy and the labour consuming traditional one of direct chromosome count should be used for refinement of discovered distinctions. $P$. pumila showed a high cytological stability when being introduced in different conditions compared to those of the natural range, which agrees with the data of Mochalova et al. $(202,2016)$. It was shown that changes of natural ploidy took place very seldom. Our study confirms that it is unlikely to find such genotypes by the deviations from morphological features typical of the species. To get similar changes, one should apply diverse special actions on the genotype, including previous obtaining polyploids and involvement of them in hybridization or conducting remote crossings. The karyological data obtained on P. pumila specimens may be used in future in introduction and breeding, including formation of polyploid genotypes.

\section{References}

1. G.V. Eremin, Pomology, Systematics of stone fruit plants (Orel, 2008) in Russian

2. A.B. Gobunov, Introduction of non-traditional fruit, berry and vegetable plants in Western Siberia (GEO, Novosibirsk, 2013) in Russian

3. I.S. Rudenko, Remote hybridization and polyploidy in fruit plants (Chişinău, Shtiintsa, 1978) in Russian

4. O.V, Mochalova, D.A. Gusev, Ach. of sc. and tech. of agr. 30, 36-39 (2016) in Russian

5. O.V, Mochalova, M.N. Matiunin, Cytoembryology and selection of remote hybrids and stone plant polyploids in Altai (SB RAS, Novosibirsk, 2002) in Russian

6. Z.P. Pausheva, Workshop on plant cytology (Agropromizdat, Moskow, 1988)

7. Cytological studies of fruit and berry crops / Guidelines (CGL, Michurinsk, 1976) in Russian

8. M. Zabka, L. Durisova, P. Elias Jr, T. Baranec, Biologia 73, 121-128 (2018)

9. W.V. Baird, A.S. Estager, J.K. Wells, J. Amer. Soc. Hort. Sci. 119, 1312-1316 (1994) 